\section{How to communicate in science}

We have read the editorial from Toes and Pisetsky ${ }^{1}$ and the letter from Holmdahl ${ }^{2}$ concerning the role of ACPA in the pathogenesis of RA.

With regards to the editorial, we appreciate the comments on how methodological hurdles may impact the interpretation of functional data. We like to add to this discussion that we have recently published data using new extensively characterised monoclonal $\mathrm{ACPAs}^{34}$ and new batches of polyclonal ACPAs ${ }^{5}$ that support a role of ACPAs in osteoclast activation and pain generation as was suggested from experiments with polyclonal ACPA in the two 2016 ARD papers. ${ }^{67}$ We have recently also published an updated protocol on the generation and testing of monoclonal ACPAs. ${ }^{8}$ We want to emphasise, however, that much work from many groups will be needed before we get a full understanding of the role of ACPAs and other antibodies from RA patients in bone erosion, pain and synovitis.

Concerning the letter from Holmdahl, ${ }^{2}$ we need to acknowledge that a personal conflict has made the communication with Holmdahl deficient and inconsistent. We have different opinions about what has been communicated, and allegations that we should have consciously concealed data from the scientific community are unwarranted. Our re-evaluation of our monoclonal antibodies was a gradual process which occurred after the publication of the two discussed ARD papers, ${ }^{67}$ notably with Holmdahl as a co-author of one of them. ${ }^{7}$

In order to conclude this discussion, scientific progress is achieved by the generation of new data but also by a re-evaluation of existing data. Whereas the most common way of reporting such re-interpretations is by dissemination in new original articles, we acknowledge that increasing use of other routes, such as correction notes ${ }^{9}{ }^{10}$ and open archives, are needed to avoid delays in communication as discussed in the editorial by Toes and Pisetsky. ${ }^{1}$

\section{Lars Klareskog $\odot{ }^{1}$ Anca Irinel Catrina, ${ }^{1}$ Camilla Svensson, ${ }^{2}$ Vivianne Malmstrom \\ ${ }^{1}$ Rheumatology Unit, Karolinska Institutet at Karolinska University Hospital, Stockholm, Sweden \\ ${ }^{2}$ Physiology and Pharmacology, Karolinska Institutet, Stockholm, Sweden}

Correspondence to Professor Lars Klareskog, Rheumatology, Karolinska Institutet, Stockholm 171 76, Sweden; lars.klareskog@ki.se

Handling editor Josef S Smolen
Contributors All the authors contributed to and approved the text.

Competing interests None declared.

Patient consent for publication Not required.

Provenance and peer review Not commissioned; internally peer reviewed.

(c) Author(s) (or their employer(s)) 2020. No commercial re-use. See rights and permissions. Published by BMJ.

\section{Check for updates}

To cite Klareskog L, Catrina Al, Svensson C, et al. Ann Rheum Dis 2020;79:e164.

Received 14 July 2019

Revised 16 July 2019

Accepted 18 July 2019

Published Online First 13 August 2019

\section{Linked}

http://dx.doi.org/10.1136/annrheumdis-2019-216045

Ann Rheum Dis 2020;79:e164. doi:10.1136/annrheumdis-2019-216016

ORCID iD

Lars Klareskog http://orcid.org/0000-0001-9601-6186

\section{REFERENCES}

1 Toes R, Pisetsky DS. Pathogenic effector functions of ACPA: where do we stand? Ann Rheum Dis 2019:78:716-21.

2 Holmdahl R. Comment on editorial 'Pathogenic effector functions of ACPA: where do we stand?'. Ann Rheum Dis 2020;79:e126.

3 Titcombe PJ, Wigerblad G, Sippl N, et al. Pathogenic citrulline-polyspecific B cell receptor clades in rheumatoid arthritis. Arthritis Rheum 2018:70:1933-45.

4 Steen J, Forsström B, Sahlström P, et al. Human plasma cell derived monoclonal antibodies to post-translationally modified proteins recognize amino acid motifs rather than specific proteins. Arthritis Rheum 2019;71:196-209.

5 Krishnamurthy A, Ytterberg AJ, Sun M, et al. Citrullination controls dendritic cell transdifferentiation into osteoclasts. J Immunol 2019;202:3143-50.

6 Krishnamurthy A, Joshua V, Haj Hensvold A, et al. Identification of a novel chemokinedependent molecular mechanism underlying rheumatoid arthritis-associated autoantibody-mediated bone loss. Ann Rheum Dis 2016;75:721-9.

7 Wigerblad G, Bas D, Cerqueria C, et al. Autoantibodies induce joint pain independent of inflammation via a chemokine-dependent mechanism. Ann Rheum Dis 2016:75:730-8.

8 Amara $\mathrm{K}$, Israelsson L, Stålesen $\mathrm{R}$, et al. A refined protocol for identifying citrullinespecific monoclonal antibodies from single human $B$ cells from rheumatoid arthritis patients. Bio Protoc. In Press 2019.

9 Anon. Correction: Identification of a novel chemokine-dependent molecular mechanism underlying rheumatoid arthritis-associated autoantibody-mediated bone loss. Ann Rheum Dis 2019;78:866.

10 Anon. Correction: Autoantibodies to citrullinated proteins induce joint pain independent of inflammation via a chemokine-dependent mechanism. Ann Rheum Dis 2019;78:865. 